Research Article

\title{
The Conditional Limitation of Relational Governance: The Moderating Role of Project Complexity
}

\author{
Jie Yang and Qian Cheng $(\mathbb{D}$ \\ School of Management Engineering, Shandong Jianzhu University, Jinan 250101, China \\ Correspondence should be addressed to Qian Cheng; chengqian835988245@163.com
}

Received 4 July 2020; Revised 26 October 2020; Accepted 28 January 2021; Published 8 February 2021

Academic Editor: Tingting Zhang

Copyright ( 2021 Jie Yang and Qian Cheng. This is an open access article distributed under the Creative Commons Attribution License, which permits unrestricted use, distribution, and reproduction in any medium, provided the original work is properly cited.

\begin{abstract}
Relational governance is generally concerned with the framework of project governance. However, this governance still has its limitations, which vary depending on contextual factors. Using transaction cost economics theory, this study considers project complexity as the moderator in studying the influence of trust as the most representative factor of relational governance in project performance. Empirical analysis with 302 owners and general contractors as a sample reveals that trust can effectively improve project performance and has a negative correlation with opportunism. The influence path of "trust-opportunism-project performance" is emphasized. The test of moderating effects shows that high project complexity increases the governance effectiveness of competence-based trust on project performance but weakens the governance effectiveness of goodwill-based trust on project performance. At the same time, high project complexity increases the governance effectiveness of goodwill-based trust on opportunism but weakens the governance effectiveness of competence-based trust on opportunism. The conclusion of this work can be used as a reference for the rational application of relational governance factors to various complex projects. This research also provides important inspiration for selecting appropriate relational governance directions to enhance project performance.
\end{abstract}

\section{Introduction}

Serious problems, such as interest disputes, construction delays, and cost overruns in construction project management, must not be ignored [1-3]. The improvement of project performance in a technically difficult and complex external environment has become a common concern in academia and practice. Relational governance is introduced into the frame of project governance to boost project performance. In the management literature, where humanistic thinking is prevalent, relational governance research has moved, being initially marginal to the mainstream. Relational governance can complement the use of formal contracts [4], enhance coordination, lower transaction costs, and improve exchange performance [5]. Scholars have confirmed the benefits of trust-based relational governance in terms of concepts [6-8] and experience [9-11]. However, researchers confirmed that certain exchange hazards, particularly asset specificity and difficult performance measurement, dampen the positive association between relational governance and performance [12]. Some scholars have also considered the impact of environmental uncertainties on relational governance and even concluded that two distinct views exist: positive correlation [13] and negative correlation [14]. The applicable environment and situations of relational governance that positively affect project performance prompt further investigation.

Project organization has the characteristics of temporary organization, team diversity, and task complexity, and these features markedly differ from those of enterprise organization [15]. Typically, a project is a complex social construct that is not only formed temporarily from a set of different organizations, but is also regarded as a temporary organization composed of various stakeholders [16]. Given the limitations of the cognitive ability of the owner and the general contractor and insufficient project information, a 
project is tentative [17]. Construction projects undergo conflicts of interest, fragmented implementation process, and unforeseen complexity [18]. Project complexity can also be affected by the level of project ambiguity and uncertainty [18], as complexity depends on the clarity of a project's objectives and values [19]. Complexity has gradually become an important perspective in project management, especially with the increasing number of megaprojects around the world [20]. A project is a unique process that is severely affected by environmental factors and is surrounded by inherent uncertainties. Improving project performance will inevitably be affected by uncertain factors such as the environment. Therefore, this article attempts to verify two issues: Does relational governance apply to all construction projects of varying complexity? Can relational governance improve project performance under different levels of construction complexity?

The current research on relational governance to improve project performance generally overlooks project complexity. The existing literature usually classifies construction projects as independent individuals, ignores the impact of the social environment wherein the construction projects are located, and presents relatively one-sided research results. Given to the different complexities of projects, the impact of relational governance on project performance should be considered separately. Prior studies have also rarely opened the theoretical "black box" of impact from the perspective of transaction cost economics to identify its mechanism and path. Transaction cost economics is "a successful story in experience" [21]. The basic assumptions of transaction cost economics pertain to the bounded rationality and opportunism of both sides of a transaction. The relational contract theory proposed by Macneil [22] emphasized that transactions are inevitably embedded in the social network in which they are located and are thus unavoidably affected by relational rules (such as trust). This embeddedness also provides a defense against opportunistic risks for transactions. Therefore, between the role of relational governance and project performance, opportunism may also have a certain influence mechanism. For detailed research and accurate results, the relationship between the owner and the general contractor is taken as the research object in this work. According to transaction cost economics theory, this research employs trust to verify the impact of relational governance on project performance and opportunism as a mediator variable. The present research also identifies project complexity as a moderator to analyze the impact of varying levels of complexity in groups. Data collection through questionnaires is vital to establish the link between relational governance and construction project performance.

\section{Theoretical Basis}

2.1. Trust. Amongst the numerous factors of relational governance, scholars generally regard trust as an important element in cooperative relationship [23]. According to project governance theory, trust in transaction is an important governance mechanism of information asymmetry
[24]; consequently, trust has been widely valued in the research of organizational relationship.

In the theoretical framework of dealing with the role of trust in economic exchange especially in transaction cost economics, the multilevel nature of trust is obvious [25]. Given the varying dimensions and types of trust in current research, in-depth analysis of the changes and interaction mechanisms of trust in different dimensions and types is also a vital concern in the study of interorganizational relationships. Rousseau et al. [26] believed that trust can be divided into three dimensions: calculus-based trust, relational trust, and institution-based trust. Conversely, Hartman [27] asserted that trust in engineering projects includes competence trust, integrity trust, and intuitive trust. In transaction cost economics, trust requires the consideration of benefits and costs. Cooperation will only be carried out when the benefits outweigh the costs [28]. Barber [29] and Gabarro [30] emphasized the importance of competence in trust, and the other corresponding dimension of trust is called goodwill, responsibility, and dependability. Accordingly, Das and Teng [31] directly divided trust into competence-based trust and goodwill-based trust in their study of strategic alliance. Competence-based trust refers to the expectation of ability and expertise performance, and goodwill-based trust means building an emotional bond with people who express concern for the welfare of the other party. Ning [32] further indicated that the two different dimensions of trust are closely related to the improvement of project performance.

2.2. Opportunism. Opportunism refers to gaining more benefits by lying, stealing, cheating, and making planned efforts to mislead, distort, and conceal [33]. Transaction cost economics holds that opportunism is the actual and artificial condition of information asymmetry, and its existence is the root of transaction costs [34]. Opportunism not only complicates the problems of economic organization, but also weakens the performance of relational governance. Moreover, opportunism reflects irrelevant and risky trading relationships with trading partners. In the case of limited rationality, information asymmetry, and contract incompleteness, traditional contract incentives and close behavioral supervision push contractors into opposing relationships, thereby inducing their opportunistic behavior [35]. Relationship embedding can completely change the logic of actors through trust, from self-interest to trust and reciprocity, and thus reduce the risk of opportunistic behavior during cooperation. Minimizing opportunism is undoubtedly one of the efficient means for improving project performance.

2.3. Project Complexity. Baccarini [36] first proposed the concept of project complexity and defined it as the difference and relevance between different project elements, which mainly consist of organizational complexity and technical complexity. Project construction is uncertain [37] and complex [38]. A project is set up around a special task and must be completed by several professional teams, so it has 
organizational complexity. Moreover, the work tasks carried out by the project always have a certain technical complexity. Williams [39] indicated that the increasing project complexity and the underestimation of that complexity by managers are the most important reasons for project failure. In project management, managers have increasingly begun to realize that, with increasing project complexity, the traditional project management methods and tools have become insufficient and limited because they cannot effectively deal with the complexity [40]. Project complexity has become an inevitable important factor in project management activities [41].

\section{Research Hypotheses}

3.1. Trust and Project Performance. From the perspective of economics, trust is a psychological expectation such that when one party has a loophole in the transaction process, the other party will not maliciously use it or even kindly remind their counterpart [42]. The existing research agrees that trust can effectively alleviate the clear barriers and thinking confrontation that are generally exhibited by both parties in the transaction and that compensate for the absence of a formal contract to restrict opportunism [43], thereby improving project management performance or promoting project success. This study extends the previous investigations and divides trust into goodwill-based trust and competence-based trust.

In a one-off construction project, the relationship between the owner and the general contractor is relatively weak. Goodwill-based trust enables members to become willing to consider each other in good faith rather than exploit each other's vulnerabilities and collaborate towards uniting the entire organization and maximally avoiding or minimizing conflicts, litigation, and claims; consequently, such a trust improves the satisfaction of both parties and partner closeness [35]. In response to high uncertainty in project implementation, good intentions for each other's behavioral expectation can improve the ability to cope with uncertainty and improve project performance [44].

Trust on the basis of confidence in the ability of partners to be competent is connected to positive expectations for common goals and thus saves supervision and implementation costs, increases attention towards work, and enhances project objectives [45]. Therefore, certain scholars have confirmed the direct impact of competence-based trust on project schedule, quality, and cost [46]. When competence-based trust exists, the owner usually believes that the contractor can propose and implement technical solutions for project objectives, thereby reducing their monitoring of and control over the contractor. This gained trust saves the owner's energy, reduces the cost of supervision, increases the space for the contractor to make decisions, and consequently enhances project performance. Accordingly, the following hypotheses are formulated:

$H 1$ : Goodwill-based trust between owner and contractor is positively associated with project performance
H2: Competence-based trust between owner and contractor is positively associated with project performance

3.2. Trust and Opportunism. The existence of trust also entails the owner's acceptance of the transaction risk. Although a successful project must be based on the trust of both parties, trust does not necessarily lead to the success of a project. A "black box theory" in the relationship still exists between the parties [47]. As Schoorman et al. [48] indicated, trust only provides confidence to the parties that they will not be deceived, and certain intermediary mechanisms for the impact of project performance should be present. Certain literature also identified intermediary mechanisms between trust and construction project performance through empirical analysis. Through a survey of Canadian construction projects, Pinto et al. [35] found that owners and contractors have different perceptions of trust, and trust indirectly affects project performance through relationship satisfaction. The discovery of these intermediary mechanisms and the opening of the "black box" of trust affecting project performance are the keys to reduce transaction risk and promote the success of the project.

Opportunism destroys the relationship between participants and reduces the level of performance [49], and trust is considered to strengthen the exchange relationship and improve the possibility of exchange success [50]. Under low trust caused by ex-ante and ex-post opportunism, lengthy and difficult negotiations are needed to prevent the occurrence of unforeseen events. Furthermore, contractual and behavioral safeguards are required to protect the contractors' interests. Conversely, under high trust, organizations are less reliant on well-designed safeguards to employ, monitor, and enforce agreements [51]. A relationship of high trust entails increased transaction governance efficiency in flexible negotiations [52]. Trust is regarded as one of the most effective mechanisms to restrain opportunism [53]. The emergence and development of goodwill-based trust can enhance communication between partners, resolve conflicts promptly, integrate the interests and goals of partners, and restrain their own opportunistic behavior so as to reduce the relationship risk between partners [54]. When a contractor is perceived to have a high level of competence, the owner will actively take defensive actions to protect himself and thus effectively prevent the opportunistic behavior of the other party. Accordingly, the following hypotheses are formulated:

H3: Goodwill-based trust between owner and contractor is negatively associated with opportunism.

H4: Competence-based trust between owner and contractor is negatively associated with opportunism.

3.3. The Moderating Role of Project Complexity. Complex projects with multiple interactions make them difficult to manage [55], a feature which is also not conductive to the establishment of trust [56]. Current research on the moderator between the relational governance and project performance is relatively scarce. Yang et al. asserted that project 
complexity plays a positive role in the connection between relationship teamwork and project success. Through empirical research, [57] found that project complexity regulates the relationship between team communication and project success.

Similarly, this study assumes that project complexity is a moderator that can significantly affect the relationship between trust and project performance. Given high project complexity, the construction project will have wide uncertainty, and numerous unforeseen problems are expected. Taking all unknown factors into account and strictly restricting the opportunistic behavior of both parties are impossible. Cannon et al. [58] used 396 pieces of data from the American Purchasing Management Association to compare and analyze the performance of governance models under varying degrees of uncertainty. Their empirical research showed that when environmental uncertainty is high, contract governance is inadequate; hence, they proposed strengthening relational governance as a safeguard against opportunism.

For highly complex projects, trust between the two parties has a high value in practical application. Goodwill-based trust enhances team cohesiveness and helps improve the psychological expectation of the project participants to achieve project objectives, thereby enhancing project performance. Competence-based trust boosts the confidence to undertake risks and solve problems and is more conducive to improve project performance. Conversely, low project complexity indicates relatively low risk and difficulty for the project participants to complete the task, and the impact of trust on project performance also decreases. As project complexity intensifies, the general contractor's opportunistic behavior tends to be more obvious, but strict contract restrictions will stimulate this behavior. At this time, goodwill-based trust and competence-based trust weaken the contractor's opportunistic behavior significantly. Accordingly, the following hypotheses are formulated:

H6a : The degree of project complexity positively affects the relationship between goodwill-based trust and project performance

$H 6 \mathrm{~b}$ : The degree of project complexity positively affects the relationship between competence-based trust and project performance

H6c : The degree of project complexity positively affects the relationship between goodwill-based trust and opportunism

H6d : The degree of project complexity positively affects the relationship between competence-based trust and opportunism

The conceptual framework of this paper is shown in Figure 1.

\section{Methodology}

4.1. Survey and Data Collection. Data were collected through field surveys and questionnaires. In view of the research perspective of this study, the survey mainly focused on owners and the general contractor management personnel who participated in construction projects of various scales. The work experience of the respondents was limited to more than three years. Construction projects in Shanxi, Shaanxi, Shandon, and Henan Provinces in China were targeted as the survey samples. Selecting these provinces mitigated the systematic deviations caused by regional culture and economic differences. Shandong belongs to the eastern developed regions, Shanxi and Henan to the central region, and Shaanxi to the western region. A total of 350 questionnaires were distributed, and 323 questionnaires were returned. The recovery rate of the questionnaire was $92.29 \%$. After strict screening, 302 questionnaires were deemed valid, and the recovery rate of the effective questionnaires reached $86.29 \%$. In response to the project complexity in the questionnaire and given the actual investigation of the projects in which the respondents participated, the 302 samples were divided into low complexity projects (143 samples) and high complexity projects (159 samples). Sample background data were summarized and analyzed according to their role in the project, job position, work experience, and project complexity. The results are shown in Table 1.

4.2. Measurement. We combined the measurement indicators in prior research with a construction project context to measure relevant variables effectively. To ensure the scientific effectiveness of the questionnaire items, small-scale distribution was initially conducted within the research team. Through interviews with relevant experts and research team members, the terms of the scale were revised and supplemented, and the final questionnaire was formed according to the experts' opinions.

The research variables of goodwill-based trust, competence-based trust, opportunism, project complexity, and project performance in this study were all measured by mature scales developed by domestic and foreign scholars and verified in the Chinese context. The items were all based on a five-point Likert scale. The five options of [disagree], [somewhat disagree], [neutral], [partially agree,] and [agree] were assigned $1-5$ points, respectively.

(1) Independent variables. Goodwill-based trust and competence-based trust: In the measurement scale, goodwill-based trust involved four items (GT1-GT4) on the basis of mutual interests, trustworthiness, mutual assistance, and commitment [59]. Competence-based trust involved four items (CT1-CT4) from the perspective of achieving project objectives, work experience, and technical level [59].

(2) Dependent variable. Project performance: By referring to the mature scale of project performance verified by scholars [35] and combining that with the actual construction project, the measurement items of project performance were finally determined. Five items (PP1-PP5) were set for project performance and involved traditional quality, the cost and duration of the "iron triangle," safety, and stakeholder satisfaction. 


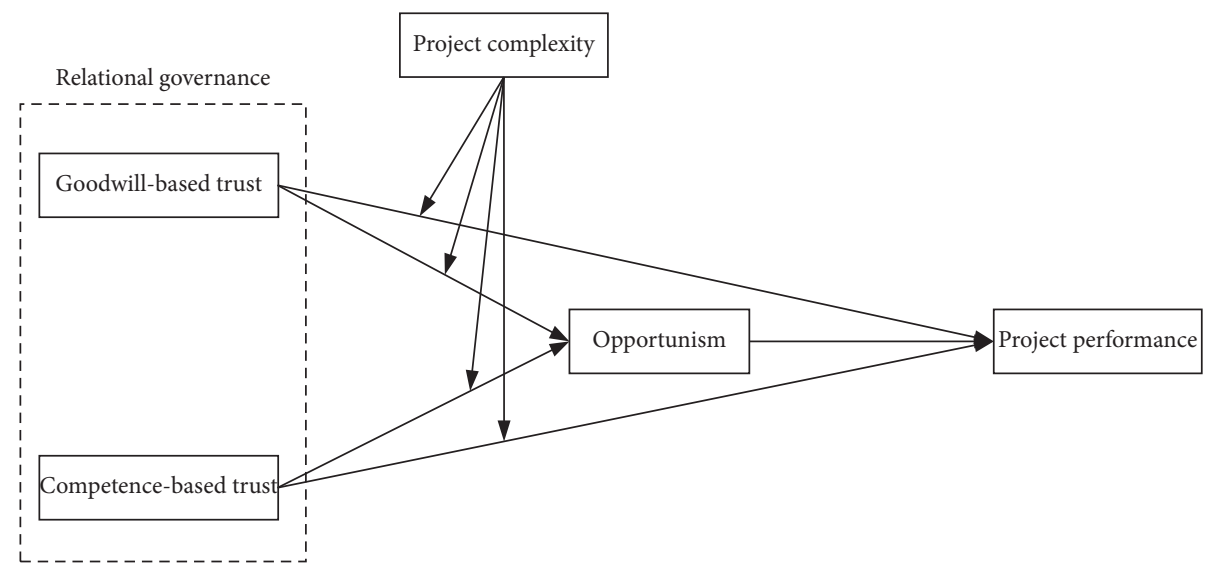

Figure 1: Conceptual framework.

TABLE 1: Sample background information.

\begin{tabular}{lccc}
\hline & Type & $N$ & $\%$ \\
\hline \multirow{2}{*}{ Character } & Owner & 94 & 31.13 \\
& Contractor & 208 & 68.87 \\
\hline \multirow{3}{*}{ Position } & Leader & 48 & 15.89 \\
& Department head & 61 & 20.20 \\
& Project manager/supervisor & 92 & 30.46 \\
\multirow{3}{*}{ Experience } & General manager & 101 & 33.44 \\
& 3-5 years & 84 & 27.81 \\
& 6-10 years & 123 & 40.73 \\
& $11-15$ years & 60 & 19.87 \\
Complexity level & More than 15 years & 35 & 11.59 \\
\hline \multirow{2}{*}{} & Low complexity & 143 & 47.35 \\
& High complexity & 159 & 52.65 \\
\hline
\end{tabular}

(3) Mediator. Opportunism: This study considered the opportunistic behaviors that arose on both sides and examined them through four items (OT1-OT4) by summary classification [60].

(4) Moderator. Project complexity: Project complexity involved four items (PC1-PC4) that considered project uncertainty, technical level, and the number of outsourcers and stakeholders [61].

The items of the measurement scale are shown in Table 2

\section{Results and Analysis}

5.1. Confirmatory Factor Analysis. This study uses confirmatory factor analysis to introduce a method factor model to test the sitting effect of the sample data [62] (see Table 3 for specific analysis results). The fitting effect of five-factor and observation data outperforms that of a single factor model and meets the statistical requirements. Thus, the main research variables involved in this study are independent and have good discrimination validity. Moreover, the model goodness of fit has a slight variation. For example, the changes of $\chi 2 / \mathrm{df}$, comparative fit index [CFI], Tucker-Lewis index [TLI], goodness-of-fit index [GFI], and root mean squared error of approximation [RMSEA] are 0.466, 0.03, $0.079,0.032$, and 0.021 , respectively, thereby indicating that the common method variance (CMV) of the observed data in this study is within the acceptable range [63].

5.2. Scale Reliability and Validity Test. The reliability of the variable is measured by Cronbach's alpha and composite reliability (CR). Table 4 shows that the Cronbach's alpha value and $C R$ value of each variable are higher than 0.7 and meet the credibility requirement [64]. Thus, the measurement items can adequately reflect the information required by the model and have high reliability and good internal consistency. The content of the scale has been carefully organized and analyzed by the existing literature and repeated expert discussion. The scale has high content validity, and a validity test was conducted using confirmatory factor analysis. The data in Tables 2 and 4 show that each factor loading is higher than 0.7 , and all average variance extracted (AVE) values exceed 0.5 , thereby indicating that the questionnaire data have high structural validity and convergent validity. In the correlation coefficient matrix of variables (Table 5), the arithmetic square root of AVE is significantly larger than the coefficient of the correlation between two different variables. Furthermore, according to the recommended standard values of Fornell and Larcker [65], the discriminatory validity is satisfactory.

5.3. Structural Model. The data after the reliability and validity tests are imported into AMOS, and the goodwillbased trust and competence-based trust of exogenous variables with high correlation are matched. The model is further modified according to the model correction coefficient. The final path analysis model in Figure 2 is thus obtained. The standardized path coefficient and its $p$ value are above the arrow line (Figure 2). The normalized path coefficient is the response of the interaction relationship between latent variables. To some extent, the magnitude of the coefficient indicates the strength of the interaction relationship.

The final software data show that the fitting indexes (IFI, CFI, NFI, and RMSEA) are in line with the standard values [66] (Table 6). The overall path analysis model has good adaptability. 
TABle 2: Constructs and items.

\begin{tabular}{|c|c|c|c|c|c|c|}
\hline \multirow[b]{2}{*}{ Construct } & \multirow[b]{2}{*}{ Items } & \multicolumn{2}{|c|}{ Component loading } & \multicolumn{2}{|c|}{ KMO } & \multirow{2}{*}{$\begin{array}{l}\text { Indicator } \\
\text { basis }\end{array}$} \\
\hline & & $\begin{array}{l}\text { Low } \\
\text { complexity }\end{array}$ & $\begin{array}{l}\text { High } \\
\text { complexity }\end{array}$ & $\begin{array}{l}\text { Low } \\
\text { complexity }\end{array}$ & $\begin{array}{l}\text { High } \\
\text { complexity }\end{array}$ & \\
\hline \multirow{4}{*}{$\begin{array}{l}\text { Goodwill-based } \\
\text { trust }\end{array}$} & $\begin{array}{l}\text { GT1 I am confident that the other party will } \\
\text { consider my interests when making decisions. }\end{array}$ & 0.732 & 0.706 & & & \multirow{4}{*}{$\begin{array}{l}\text { Lui and Ngo } \\
\text { [59] }\end{array}$} \\
\hline & GT2 I think the other party is trustworthy. & 0.742 & 0.720 & & & \\
\hline & $\begin{array}{l}\text { GT3 I believe that other party is willing to help } \\
\text { when we are in trouble. }\end{array}$ & 0.721 & 0.842 & 0.781 & 0.855 & \\
\hline & $\begin{array}{l}\text { GT4 I believe that the other party could keep } \\
\text { his/her promise throughout the life of the } \\
\text { project. }\end{array}$ & 0.811 & 0.737 & & & \\
\hline \multirow{4}{*}{$\begin{array}{l}\text { Competence- } \\
\text { based trust }\end{array}$} & $\begin{array}{l}\text { CT1 on the basis of the other party's } \\
\text { performance record and good reputation, I } \\
\text { believe that the other party has the ability to } \\
\text { complete future projects. }\end{array}$ & 0.780 & 0.738 & \multirow{4}{*}{0.825} & \multirow{4}{*}{0.832} & \multirow{4}{*}{$\begin{array}{l}\text { Lui and Ngo } \\
{[59]}\end{array}$} \\
\hline & $\begin{array}{l}\text { CT2 I believe that the other party has a wealth } \\
\text { of expertise in the project. }\end{array}$ & 0.784 & 0.773 & & & \\
\hline & $\begin{array}{l}\text { CT3 I believe that the construction quality of } \\
\text { the other party is high. }\end{array}$ & 0.714 & 0.742 & & & \\
\hline & $\begin{array}{l}\text { CT4 I believe that the skill level of the other } \\
\text { party is high. }\end{array}$ & 0.773 & 0.762 & & & \\
\hline \multirow{4}{*}{ Opportunism } & $\begin{array}{l}\text { OT1 The problems that arise during the } \\
\text { cooperation process are often seen by the other } \\
\text { party as our responsibility. }\end{array}$ & -0.706 & -0.709 & \multirow{4}{*}{0.847} & \multirow{4}{*}{0.817} & \multirow{4}{*}{$\begin{array}{l}\text { Wuyts and } \\
\text { Geyskens [60] }\end{array}$} \\
\hline & $\begin{array}{l}\text { OT2 The other party is always committed to } \\
\text { improvement that can bring benefits to } \\
\text { oneself. }\end{array}$ & -0.793 & -0.700 & & & \\
\hline & $\begin{array}{c}\text { OT3 The other party is unwilling to avoid } \\
\text { making decisions that may seriously damage } \\
\text { our interests. }\end{array}$ & -0.740 & -0.711 & & & \\
\hline & $\begin{array}{l}\text { OT4 when making major decisions, the other } \\
\text { party will not fully consider our interests. }\end{array}$ & -0.704 & -0.762 & & & \\
\hline \multirow{5}{*}{$\begin{array}{l}\text { Project } \\
\text { performance }\end{array}$} & $\begin{array}{c}\text { PP1 The project construction cost is in line } \\
\text { with the contract. }\end{array}$ & 0.731 & 0.713 & \multirow{5}{*}{0.844} & \multirow{5}{*}{0.888} & \multirow{5}{*}{$\begin{array}{l}\text { Pinto et al. } \\
\qquad[35]\end{array}$} \\
\hline & $\begin{array}{l}\text { PP2 The completion time of the project is in } \\
\text { line with the schedule. }\end{array}$ & 0.705 & 0.717 & & & \\
\hline & $\begin{array}{c}\text { PP3 The quality of project delivery complies } \\
\text { with national standards and contractual } \\
\text { standards. }\end{array}$ & 0.750 & 0.705 & & & \\
\hline & $\begin{array}{l}\text { PP4 during the course of the project, no safety } \\
\text { incidents occurred and the safety objectives } \\
\text { specified in the contract were met. }\end{array}$ & 0.845 & 0.860 & & & \\
\hline & $\begin{array}{l}\text { PP5 all participants in the project are satisfied } \\
\text { with the delivered projects. }\end{array}$ & 0.716 & 0.767 & & & \\
\hline $\begin{array}{l}\text { Project } \\
\text { complexity }\end{array}$ & $\begin{array}{l}\text { PC1 The technical level required for this } \\
\text { project was high. } \\
\text { PC2 there are many uncertainties in this } \\
\text { project. } \\
\text { PC3 this project involved many professional } \\
\text { subcontractors. } \\
\text { PC4 this project involved many stakeholders. }\end{array}$ & & & & & $\begin{array}{l}\text { Xia and Lee } \\
{[61]}\end{array}$ \\
\hline
\end{tabular}

TABLE 3: Confirmatory factor analysis results.

\begin{tabular}{lcccrr}
\hline Model & $\chi^{2} / \mathrm{df}$ & CFI & TLI & GFI & RMSEA \\
\hline Single-factor model & 2.436 & 0.902 & 0.898 & 0.900 & 0.078 \\
Five-factor model & 1.970 & 0.932 & 0.977 & 0.932 & 0.057 \\
\hline
\end{tabular}

Evaluation standard of index goodness of fit: $\chi^{2} / \mathrm{df}<3$, CFI $>0.9$, TLI $>0.9$, GFI $>0.9$ and RMSEA $<0.08$. 
TABLE 4: Measurement reliability and convergent validity assessment.

\begin{tabular}{lccc}
\hline Constructs & Index & Low complexity & High complexity \\
\hline \multirow{3}{*}{ Goodwill-based trust } & Cronbach's alpha & 0.900 & 0.923 \\
& CR & 0.839 & 0.839 \\
& AVE & 0.566 & 0.567 \\
Competence-based trust & Cronbach's alpha & 0.896 & 0.872 \\
& CR & 0.850 & 0.841 \\
\hline \multirow{3}{*}{ Opportunism } & AVE & 0.587 & 0.569 \\
& Cronbach's alpha & 0.965 & 0.908 \\
Project performance & CR & 0.826 & 0.812 \\
& AVE & 0.543 & 0.520 \\
\hline
\end{tabular}

TABLE 5: AVE and correlation matrix.

\begin{tabular}{lccc}
\hline & 1 & 2 & 3 \\
\hline (1) Goodwill-based trust & $0.752 / 0.753$ & & \\
(2) Competence-based trust & $0.381 / 0.367$ & $0.766 / 0.754$ & \\
(3) Opportunism & $-0.551 /-0.470$ & $-0.463 /-0.30$ & $0.737 / 0.721$ \\
(4) Project performance & $0.587 / 0.442$ & $0.402 / 0.362$ & $-0.541 /-0.350$ \\
\hline
\end{tabular}

Low complexity/high complexity; the diagonal line is the arithmetic square root of each variable AVE, and the area below the diagonal line is the correlation coefficient between variables.

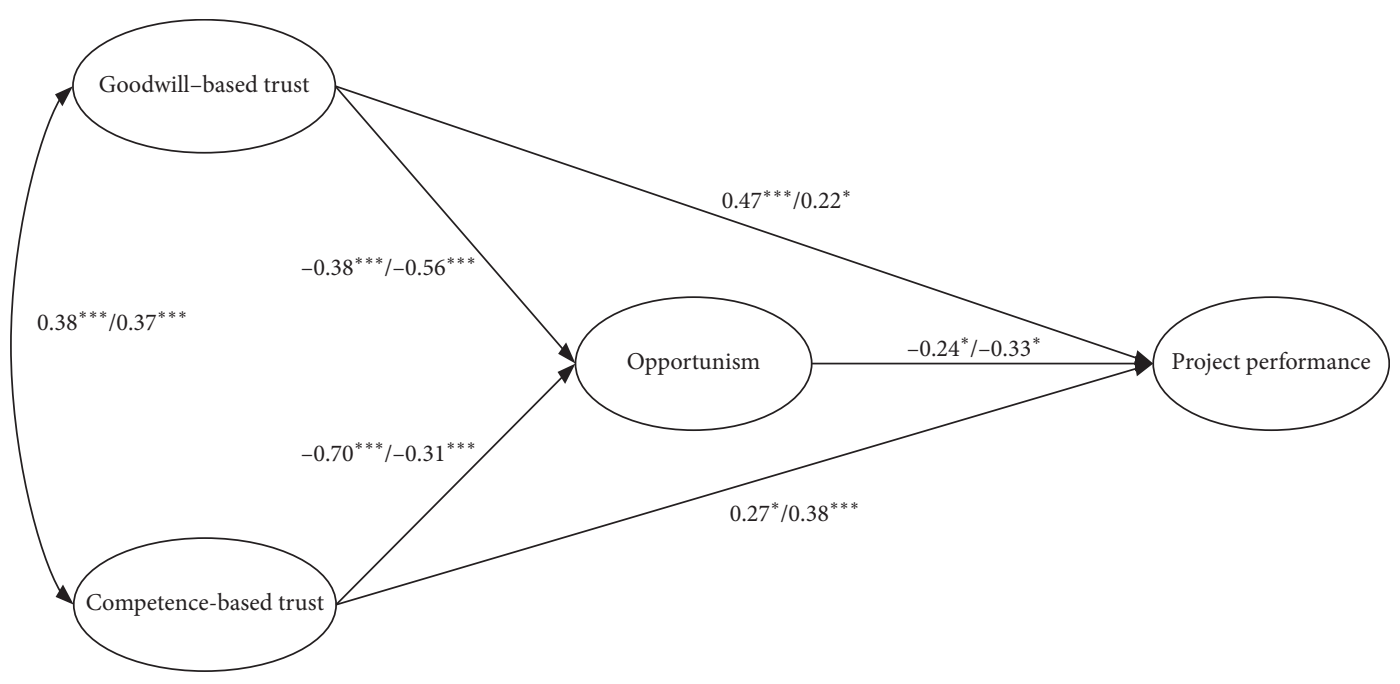

FIgURe 2: Results of the path analysis model.

TABLE 6: Goodness-of-fit statistics.

\begin{tabular}{lccccc}
\hline Index & CMIN $/$ df & RMSEA & IFI & CFI & NFI \\
\hline Result & $1.968<3$ & $0.057<0.08$ & $0.958>0.90$ & $0.958>0.90$ & $0.918>0.90$ \\
\hline
\end{tabular}

5.4. Hypothesis Testing. Sample data are divided into low complexity and high complexity groups by AMOS software for analysis. The results of the data analysis are shown in Table 7. In low project complexity scenarios, the positive effect of goodwill-based trust on project performance is significant $(p<0.001)$. However, in high project complexity scenarios, the impact remains valid, but the significance is weak $(p<0.05)$. Therefore, hypothesis 1 is supported in both scenarios. By contrast, the positive effect of competencebased trust on project performance under the low project complexity is weak $(p<0.05)$. Nevertheless, the impact is significant $(p<0.001)$ given high project complexity. 
TABLE 7: Hypothesis test results.

\begin{tabular}{lcccccc}
\hline Hypothesis & Path & Estimate & S.E. & C.R. & $p$ & Hypothesis supported \\
\hline$H 1$ & GT $\longrightarrow$ PP & $0.437 / 0.222$ & $0.082 / 0.105$ & $5.744 / 2.117$ & $* * * / *$ & Yes/Yes \\
$H 2$ & CT $\longrightarrow$ PP & $0.271 / 0.382$ & $0.131 / 0.097$ & $2.061 / 3.959$ & $* / * * *$ & Yes/Yes \\
$H 3$ & GT $\longrightarrow$ OT & $-0.374 /-0.564$ & $0.064 / 0.073$ & $-5.865 /-7.731$ & $* * * / * * *$ & Yes/Yes \\
$H 4$ & CT $\longrightarrow$ OT & $-0.698 /-0.306$ & $0.096 / 0.082$ & $-7.298 /-3.736$ & $* * * / * * *$ & Yes/Yes \\
$H 5$ & OT $\longrightarrow$ PP & $-0.236 /-0.332$ & $0.119 / 0.140$ & $-1.989 /-2.372$ & $* / *$ & Yes/Yes \\
\hline
\end{tabular}

Low complexity/high complexity; ${ }^{* * *} p<0.001,{ }^{* *} p<0.01,{ }^{*} p<0.05 ; \mathrm{GT}=$ goodwill-based trust, $\mathrm{CT}=$ competence-based trust, OT $=$ opportunism, $\mathrm{PP}=$ project performance.

Similarly, hypothesis 2 holds for both project complexity levels. Under low project complexity or high project complexity, goodwill-based trust and competence-based trust have significant negative effects on opportunism. Therefore, hypotheses 3 and 4 are supported under two different project complexities. In view of the negative impact of opportunism on project performance, hypothesis 5 is valid under different project complexities $(p<0.05)$.

5.5. Mediation Analysis. We assume that $\mathrm{H} 3, \mathrm{H} 4$, and $\mathrm{H} 5$ are established simultaneously, thereby indicating that the paths of "goodwill-based trust-opportunism-project performance" and "competence-based trust-opportunism-project performance" are established and that opportunism plays a part of the mediating role in the relationship between trust and project performance. To prove this assertion, the bootstrapping method [67] is used to further analyze the mediating role of opportunism in the relationship between trust and project performance. By calculating the standard values of the total effect, direct effect, and indirect effect of each path, opportunism is proven to play a part of the mediating role in the relationship between trust and project performance under different project complexities (Table 8).

5.6. Moderation Analysis. The bootstrap coefficient is used to examine the moderating effects of project complexity. The test results are shown in Table 9. In the four-path analysis, the positive impact of goodwill-based trust and competencebased trust on project performance and the negative impact of goodwill-based trust and competence-based trust on opportunism are disturbed by the project complexity $(p<0.05)$.

With the increase of goodwill-based trust, project performance improved, and the relationships between competence-based trust and project performance are similar (Figure 3(a)). However, project complexity plays a different moderating role. Compared with the case with low project complexity, the effectiveness of competence-based trust in improving project performance is significantly improved under high project complexity. By contrast, high project complexity weakens the governance effectiveness of goodwill-based trust on project performance. With the increase of goodwill-based trust, the opportunism of the general contractor decreases, and the relationships between competence-based trust and opportunism are similar (Figure 3(b)). Project complexity also plays a different moderating role.
High project complexity increases the governance effectiveness of goodwill-based trust on opportunism but weakens the governance effectiveness of competence-based trust on opportunism.

\section{Discussion}

On basis of the theory of transaction cost economics, this study analyzes the influencing degree and improvement mechanism of trust between the owner and the general contractor on project performance under different complexities. Through the comparative analysis of group experiments, we established that the trust between the owner and the general contractor, which is a representative factor of relational governance, has certain situational and restrictive effects on improving performance. Therefore, in engineering practice, the application of relational governance should have a different emphasis according to the project complexity.

6.1. Impact of Trust on Opportunism. Reducing transaction cost through various control mechanisms is the fundamental driving force for the existence of transaction relationship [68]. From the perspective of transaction cost economics, the most convincing evidence of the significant effect of trust on organizational relationship is that trust reduces the tendency of opportunistic behavior [69, 70]. Moreover, the impact of trust on opportunism is moderated by project complexity. Compared with goodwill-based trust, competence-based trust has a stronger negative correlation with opportunism under low project complexity. In projects with low complexity, the lack of cooperation experience between the owner and the contractor leads to low cognitive trust. Often, the contractor is chosen because of their good experience and technical ability. The owner has a high competencebased trust in the contractor, an aspect which enhances the contractor's confidence in achieving the project objectives.

With the increase of project complexity, goodwill-based trust presents a relatively strong negative correlation with opportunism. Project members must be gathered into a behavior group that integrates various interdisciplinary technologies to fulfil the needs of project success. Owners usually choose contractors with good reputations, with whom they have previously cooperated, and who have the cognitive attributes of long-term cooperation. The emergence and development of goodwill-based trust can enhance communication between the two sides, resolve conflicts promptly, integrate their respective interests and objectives, 
TABLE 8: The mediating role of opportunism.

\begin{tabular}{lcccc}
\hline Project complexity & Path & Standardised effect & Value & Mediation effect \\
\hline & $\mathrm{GT} \longrightarrow \mathrm{PP}$ & Total effect & 0.563 \\
& $\mathrm{GT} \longrightarrow \mathrm{PP}$ & Direct effect & 0.474 & 0.089 \\
Low complexity & $\mathrm{GT} \longrightarrow \mathrm{OT} \longrightarrow \mathrm{PP}$ & Indirect effect & 0.337 \\
& $\mathrm{CT} \longrightarrow \mathrm{PP}$ & Total effect & 0.208 \\
& $\mathrm{CT} \longrightarrow \mathrm{PP}$ & Direct effect & 0.128 \\
\hline $\mathrm{CT} \longrightarrow \mathrm{OT} \longrightarrow \mathrm{PP}$ & Indirect effect & 0.462 \\
High complexity & $\mathrm{GT} \longrightarrow \mathrm{PP}$ & Total effect & 0.251 & 0.128 \\
& $\mathrm{GT} \longrightarrow \mathrm{PP}$ & Direct effect & 0.211 & 0.450 \\
& $\mathrm{GT} \longrightarrow \mathrm{OT} \longrightarrow \mathrm{PP}$ & Indirect effect & 0.356 \\
$\mathrm{CT} \longrightarrow \mathrm{PP}$ & Total effect & 0.094 \\
\hline $\mathrm{CT} \longrightarrow \mathrm{PP}$ & Direct effect & Indirect effect & 0.094 \\
\hline
\end{tabular}

$\mathrm{GT}=$ goodwill-based trust, $\mathrm{CT}=$ competence-based trust, $\mathrm{OT}=$ opportunism, $\mathrm{PP}=$ project performance.

TABle 9: Multigroup comparison test results.

\begin{tabular}{|c|c|c|c|c|}
\hline Path & $\mathrm{GT} \longrightarrow \mathrm{PP}$ & $\mathrm{CT} \longrightarrow \mathrm{PP}$ & $\mathrm{GT} \longrightarrow \mathrm{OT}$ & $\mathrm{CT} \longrightarrow \mathrm{OT}$ \\
\hline $\mathrm{P}_{\text {Henseler }}$ & $0.003^{* *}$ & $0.002^{* *}$ & $0.032^{*}$ & $0.048^{*}$ \\
\hline
\end{tabular}

and restrain their speculative behavior, thereby reducing the risks in a partnership [71]. This outcome is also in line with the Chinese social background of focusing on interpersonal relationships. With the continuation of the transaction and the deepening of the relationship, the owner and the general contractor gradually generate trust and commitment that are more conductive to future cooperation, rather than only considering the technical ability and implementation degree. This development promotes the positive expectations for the relationship between the two parties and lays a good foundation for future long-term cooperation. Effective relationship governance mechanisms such as trust, communication, and commitment amongst partners can increase the explicit and implicit costs of speculation and avoid opportunistic behaviors.

6.2. Impact of Trust on Project Performance. Drafting a contract that can cover all the transaction details and unexpected situations is almost impossible and will cause huge economic costs, a situation that goes against the original intention of the cooperation between the owner and the general contractor. Trust-based relational governance compensates for the shortcomings of contract governance at a low cost and is an inevitable product of the development of the cooperation process between the two parties [72]. Formal contracts usually have poor environmental adaptability. Once the background of cooperation changes, owners tend to choose the informal control on the basis of trust to increase the probability of relationship continuity [73].

On one hand, trust has a direct impact on project performance, and its impact is moderated by project complexity. By comparing group experiments, we find that goodwill-based trust has a greater impact on project performance under low project complexity, although this effectiveness will be weakened with the increase of project complexity. Project uncertainty is relatively slight, and the stakeholders involved are relatively limited under low project complexity. Direct communication and coordination to resolve practical problems becomes easy according to the goodwill-based trust from both sides, thereby improving project performance. Emotional trust enables both parties to consider each other out of goodwill without taking advantage of loopholes [46]. This trust avoids or minimizes conflicts, litigation, and claims and consequently enhances stakeholder satisfaction and partner closeness. With the increasing complexity of engineering projects, the impact of competence-based trust on project performance intensifies. Engineering projects with large-scale complexity, clear division of labor, and technical complexity require a high level of professional competence. The owner gives the necessary competence-based trust to the contractor, a feature that is beneficial to both parties in committing to ideal resource allocation and work efficiency to achieve common goals.

On the other hand, the associated path of trustopportunism-project performance" exists in the mechanism of trust on project performance. Opportunistic behavior is one of the main risks faced by the cooperation between the owner and the contractor [74]. As Jap and Anderson [75] indicated, a party with an opportunistic motive will resort to deceptive or distorted information to achieve its outcome. The external environment of distrust often leads to the emergence of opportunistic behavior, which, in turn, aggravates the mutual distrust and nonstandard behavior of the partners and results in the instability and uncertainty of the cooperation. Reducing or preventing opportunistic behavior depends on the effective integrity-binding mechanism, and the favorable trust environment between the owner and the general contractor is the fertile ground for nurturing these mechanisms. Therefore, a closer trust relationship between two parties means they are less likely to exhibit opportunistic behavior, and this situation effectively improves project performance.

6.3. Goodwill-Based Trust and Competence-Based Trust. The relevance of goodwill-based trust and competencebased trust has also been verified in this experiment. After competence-based trust is established, the owner believes 

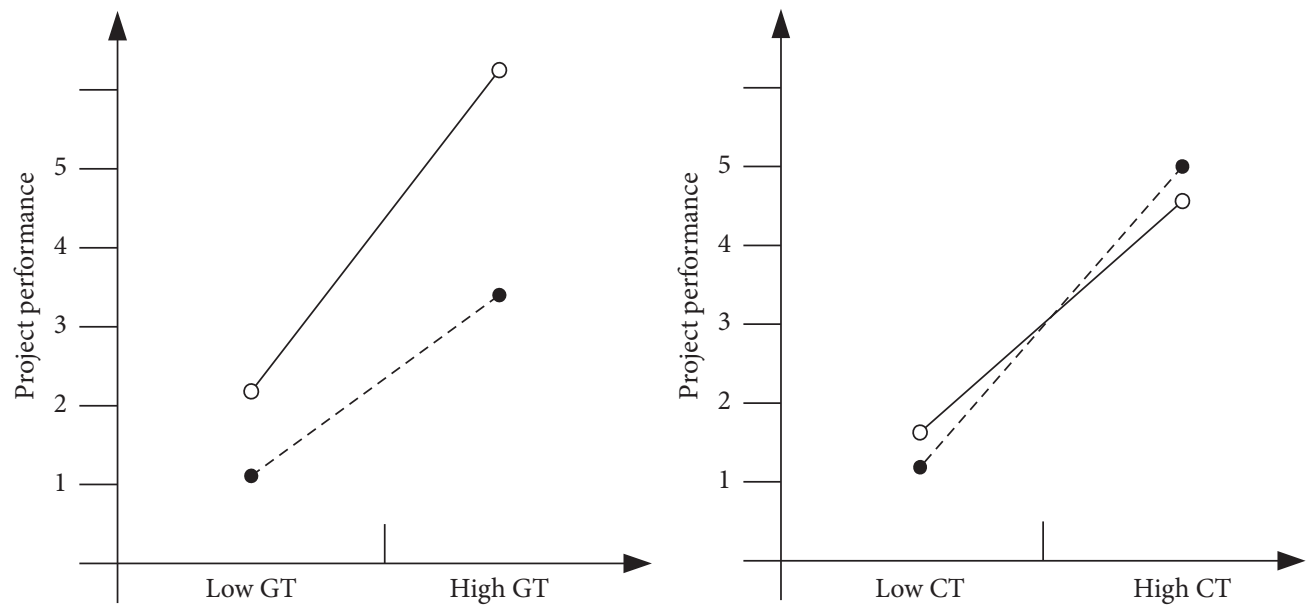

○- Low complexity

$\bullet$ High complexity

(a)
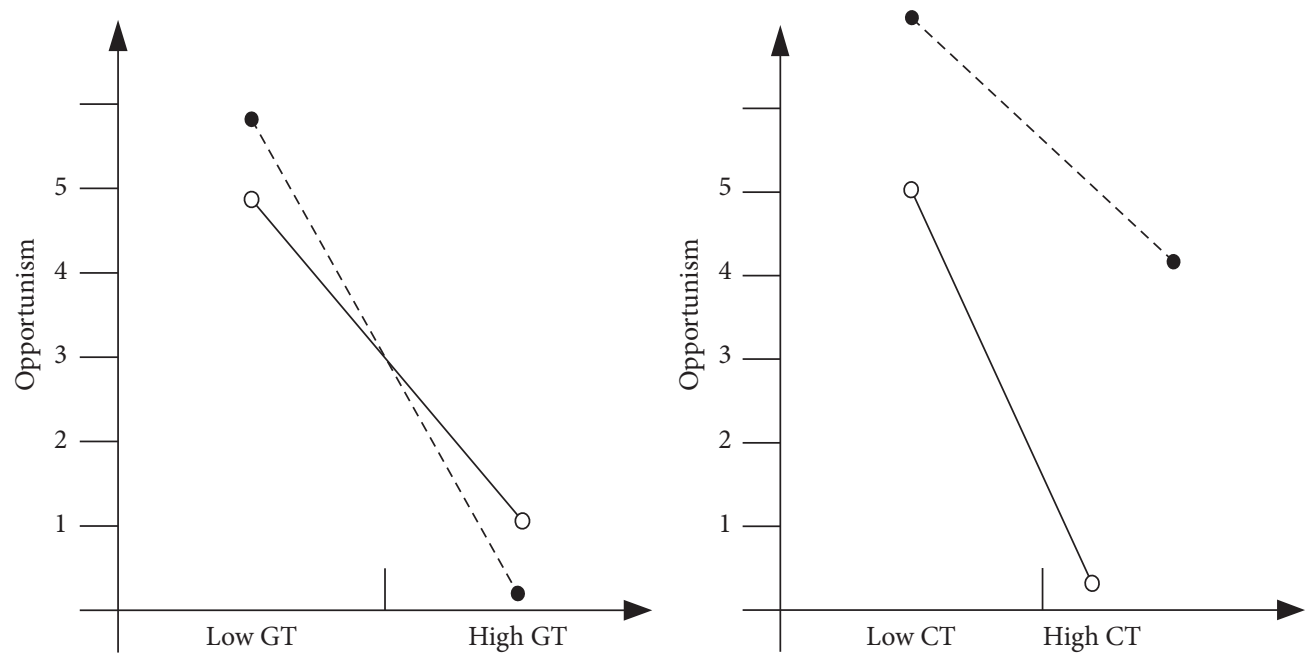

○- Low complexity

$\bullet$ High complexity

(b)

FIGURE 3: Graphical representation of moderation effects. (a) Impact of trust on project performance. (b) Impact of trust on opportunism. Notes: CT, competence-based trust; GT, goodwill-based trust.

that the contractor has taken effective measures to ensure the success of the project. Therefore, the owner is willing to believe that the contractor will act to protect the interests of the owner whilst not harming his or her own interests, thereby forming goodwill-based trust in the contractor. Similarly, after establishing goodwill-based trust, the owner (a) actively seeks clues to prove that the contractor has the ability to complete the project and (b) is willing to believe that the contractor can guarantee the implementation of the project. As a result, the owner establishes competencebased trust with the contractor. Complementarity between goodwill-based trust and competence-based trust exists and can facilitate the creation of an external environment of trust through the mutual assistance of the two dimensions of trust. Trust often determines the success of a project by consolidating relationships amongst key stakeholders $[76,77]$. In the context of incomplete contracts, trust is an invisible factor in solving practical problems and imperceptibly affects project performance. Starting from the actual improvement of project performance, fostering the trust environment between the owner and the general contractor is an imperative means for the transformation and development of the construction industry. The environment of trust between the two sides should be developed on the basis of various dimensions of trust. Through the mutual promotion and complementation of goodwill-based trust and competence-based trust, the formation of a high degree trust is conducive to optimizing contract terms, strengthening information communication, and making mutual commitments, thereby reducing uncertainty and promoting better cooperation between the two sides. 


\section{Conclusion}

The beneficial effects of relational governance factors on project governance have been extensively studied in the existing literature. However, the finiteness of those factors has been neglected. From the perspective of transaction cost economics, this work employs opportunism as a mediator and project complexity as a moderating variable to verify the difference of trust as a key factor of relational governance on project performance. This work attempts to ascertain whether relational governance factors can effectively improve project performance for different project complexities. The current research presents a certain practical application value to improve project performance in theory and practice.

In theory, this study divided trust into goodwill-based trust and competence-based trust and confirmed the direct impact of those two dimensions of trust on project performance and their indirect impact on project performance through opportunism under different project complexities. The effectiveness of competence-based trust in improving project performance is significantly improved under high project complexity. By contrast, high project complexity weakens the governance effectiveness of goodwill-based trust on project performance. At the same time, high project complexity increases the governance effectiveness of goodwill-based trust on opportunism but weakens the governance effectiveness of competence-based trust on opportunism. The theoretical contribution of this work is to broaden the perspective of relational governance research. This investigation does not simply examine the direct impact of relational governance on project performance or focus on the positive effects of relational governance. The conclusion of this study enlightens us about the fact that the implementation and application of relational governance are influenced by specific situational factors and should be analyzed specifically for projects with different complexities.

Practice shows that relying only on the formal system to implement rigid constraints to reduce opportunistic behavior amongst members has failed to achieve satisfactory results, and trust is an effective means to remedy the loopholes in incomplete contracts under the weak governance of the formal system [73]. To compensate for the incompleteness of the contract, the owner tries to increase its flexibility clause. Under the opportunistic expectations of both parties, the design of the flexibility clause requires not only the identification of project uncertainty by both parties, but also the trust to compensate for the suspicion caused by the asymmetric information [8]. Therefore, from the perspective of management implication, relational governance factors play a practical role in reducing the opportunistic behavior of both parties, whether during contract formation or contract implementation. Given the unique and dynamic characteristics of project complexity, engineering managers can form the best practice suitable for the project by virtue of the previous project complexity and dynamically adjust the management direction according to the actual situation of the project during its implementation. Engineering managers must actively establish effective relational governance mechanisms such as trust, communication, and commitment with partners so as to increase the explicit and hidden costs of speculation and avoid the occurrence of opportunistic behavior. Creating an organizational atmosphere of trust enables all stakeholders to strengthen trust, thereby reducing the time and cost for both parties to monitor possible problems with the other party.

In future, the integrated cooperation mode will become an inevitable trend adapted by the new era with the transformation, upgrade, and development of the construction industry. Moreover, project performance will gradually become a realistic concern amongst engineering management circles. The owner should ideologically transform the contractor into a partner and solve problems with the latter through active negotiation and mutual trust. Paying attention to humanistic factors can better explain the complex and changeable reality. The effective involvement of relational governance factors in the project management process has practical significance for promoting the longtime development of the construction industry. The relational governance factors that improve project performance are specifically analyzed according to project complexity. Naturally, we cannot ignore the importance of contract governance whilst considering relational governance. As an informal system, relational governance is an effective complement to the formal system [78]. Only the balanced implementation of the two governance systems can effectively improve project performance.

\section{Limitation and Future Research}

Firstly, trust is selected for confirmatory analysis as the most representative factor of relational governance. However, relational governance is a multidimensional concept, and the results remain one-sided. Therefore, the key factors of relational governance should be analyzed further. Secondly, only few projects in relatively developed cities of China have been investigated on the spot within the scope of capacity. Future research can collect considerable data from domestic and foreign cities and should extensively investigate the improvement of the performance of construction projects.

In addition, two shortcomings can direct follow-up research. The external parallel relationship between the owner and the general contractor is transformed into a coordinated internal relationship. Relational governance applies not only to the owners and the general contractors, but also to the relationship between stakeholders, such as that between general contractors and subcontractors and that between general contractors and suppliers. In the future, countries should conduct in-depth investigations on relational governance within their territories. For example, as China is a relationship-based society, managers in China tend to adopt relational governance rather than relying solely on contract governance in practice.

\section{Data Availability}

The data used to support the findings of this study are available from the corresponding author upon request. 


\section{Disclosure}

The founding sponsors had no role in the design of the study; in the data collection, analyses, and interpretation; in the writing of the manuscript; and in the decision to publish the results.

\section{Conflicts of Interest}

The authors declare no conflicts of interest.

\section{Acknowledgments}

This research received funding from Major Financial application projects of Shandong Province, China (CJ-2017-04).

\section{References}

[1] J. K. Larsen, G. Q. Shen, S. M. Lindhard, and T. D. Brunoe, "Factors affecting schedule delay, cost overrun, and quality level in public construction projects," Journal of Management in Engineering, vol. 32, no. 1, Article ID 04015032, 2015.

[2] S. Shokri, S. Ahn, S. Lee, C. Haas, and R. Haas, "Current status of interface management in construction: drivers and effects of systematic interface management," Journal of Construction Engineering and Management, vol. 142, no. 2, Article ID 04015070, 2015.

[3] G. Wu, C. Liu, X. Zhao, and J. Zuo, "Investigating the relationship between communication-conflict interaction and project success among construction project teams," International Journal of Project Management, vol. 35, no. 8, pp. 1466-1482, 2017.

[4] P. Lu, L. Qian, Z. Chu, and X. Xu, "Role of opportunism and trust in construction projects: empirical evidence from China," Journal of Management in Engineering, vol. 32, no. 2, Article ID 05015007, 2015.

[5] R. Joslin and R. Müller, "The relationship between project governance and project success," International Journal of Project Management, vol. 34, no. 4, pp. 613-626, 2016.

[6] J. H. Dyer and H. Singh, "The relational view: cooperative strategy and sources of interorganizational competitive advantage," Academy of Management Review, vol. 23, no. 4, pp. 660-679, 1998.

[7] B. Uzzi, "Social structure and competition in interfirm networks: the paradox of embeddedness," Administrative Science Quarterly, vol. 42, no. 1, pp. 35-67, 1997.

[8] R. Zaghloul and F. Hartman, "Construction contracts: the cost of mistrust," International Journal of Project Management, vol. 21, no. 6, pp. 419-424, 2003.

[9] G. Girmscheid and C. Brockmann, "Inter-and intraorganizational trust in international construction joint ventures," Journal of Construction Engineering and Management, vol. 136, no. 3, pp. 353-360, 2009.

[10] J. H. Dyer and W. Chu, "The role of trustworthiness in reducing transaction costs and improving performance: empirical evidence from the United States, Japan, and Korea," Organization Science, vol. 14, no. 1, pp. 57-68, 2003.

[11] L. Poppo and T. Zenger, "Do formal contracts and relational governance function as substitutes or complements?" Strategic Management Journal, vol. 23, no. 8, pp. 707-725, 2002.

[12] L. Poppo, K. Z. Zhou, and T. R. Zenger, "Examining the conditional limits of relational governance: specialized assets, performance ambiguity, and long-standing ties," Journal of Management Studies, vol. 45, no. 7, pp. 1195-1216, 2008.

[13] S. J. Carson, A. Madhok, and T. Wu, "Uncertainty, opportunism, and governance: the effects of volatility and ambiguity on formal and relational contracting," Academy of Management Journal, vol. 49, no. 5, pp. 1058-1077, 2006.

[14] K. M. Sutcliffe and A. Zaheer, "Uncertainty in the transaction environment: an empirical test," Strategic Management Journal, vol. 19, no. 1, pp. 1-23, 1998.

[15] J. R. Turner, "Towards a theory of project management: the nature of the project governance and project management," International Journal of Project Management, vol. 2, no. 24, pp. 93-95, 2006.

[16] M. Hobday, "Product complexity, innovation and industrial organisation,” Research Policy, vol. 26, no. 6, pp. 689-710, 1998.

[17] C. O. Cruz and R. C. Marques, "Flexible contracts to cope with uncertainty in public-private partnerships," International Journal of Project Management, vol. 31, no. 3, pp. 473-483, 2013.

[18] S. Cicmil and D. Marshall, "Insights into collaboration at the project level: complexity, social interaction and procurement mechanisms," Building Research \& Information, vol. 33, no. 6, pp. 523-535, 2005.

[19] J. R. Turner and R. A. Cochrane, "Goals-and-methods matrix: coping with projects with ill defined goals and/or methods of achieving them," International Journal of Project Management, vol. 11, no. 2, pp. 93-102, 1993.

[20] Y. Li, Y. Lu, J. E. Taylor, and Y. Han, "Bibliographic and comparative analyses to explore emerging classic texts in megaproject management," International Journal of Project Management, vol. 36, no. 2, pp. 342-361, 2018.

[21] Adelstein and Richard, The Mechanisms of Governance, O. E. Williamson, Ed., Oxford University Press, New York, NY, USA, 1996.

[22] I. R. Macneil, "The many futures of contracts," Southern California Law Review, vol. 47, no. 1, pp. 691-816, 1974.

[23] K. Wysienska-Di Carlo and Z. Karpinski, An Experimental Study of Status Effects on Trust and Cooperation, SAGE Publications Ltd, Thousand Oaks, CA, USA, 2018.

[24] D. Faems, M. Janssens, A. Madhok, and B. V. Looy, “Toward an integrative perspective on alliance governance: connecting contract design, trust dynamics, and contract application," Academy of Management Journal, vol. 51, no. 6, pp. 10531078, 2008.

[25] O. E. Williamson, Markets and Hierarchies, American Economic Association, New York, NY, USA, 1975.

[26] D. M. Rousseau, S. B. Sitkin, R. S. Burt, and C. Camerer, "Not so different after all: a cross-discipline view of trust," Academy of Management Review, vol. 23, no. 3, pp. 393-404, 1998.

[27] F. T. Hartman, "The role of trust in project management," 2002.

[28] O. E. Williamson, "Calculativeness, trust, and economic organization," The Journal of Law and Economics, vol. 36, no. 1, pp. 453-486, 1993.

[29] B. Barber, The Logic and Limits of Trust, Rutgers University Press, New Brunswick, NJ, USA, 1983.

[30] J. J. Gabarro, The Development of Trust, Influence and Expectations, Gabarro, Interpersonal Behavior: Communication \& Understanding in Relationships, Prentice-Hall, Englewood Cliffs, NJ, USA, 1978.

[31] T. K. Das and B.-S. Teng, "Trust, control, and risk in strategic alliances: an integrated framework," Organization Studies, vol. 22, no. 2, pp. 251-283, 2001. 
[32] Y. Ning, "Combining formal controls and trust to improve dwelling fit-out project performance: a configurational analysis," International Journal of Project Management, vol. 35, no. 7, pp. 1238-1252, 2017.

[33] S. S. Lui, Y.-y. Wong, and W. Liu, "Asset specificity roles in interfirm cooperation: reducing opportunistic behavior or increasing cooperative behavior?" Journal of Business Research, vol. 62, no. 11, pp. 1214-1219, 2009.

[34] O. E. Williamson, The Mechanisms of Governance, Oxford University Press, Oxford, UK, 1996.

[35] J. K. Pinto, D. P. Slevin, and B. English, "Trust in projects: an empirical assessment of owner/contractor relationships," International Journal of Project Management, vol. 27, no. 6, pp. 638-648, 2009.

[36] D. Baccarini, "The concept of project complexity-a review," International Journal of Project Management, vol. 14, no. 4, pp. 201-204, 1996.

[37] O. Perminova, M. Gustafsson, and K. Wikström, "Defining uncertainty in projects - a new perspective," International Journal of Project Management, vol. 26, no. 1, pp. 73-79, 2008.

[38] H. Wood and P. Ashton, "Factors of complexity in construction projects," 2009.

[39] T. Williams, "Assessing and moving on from the dominant project management discourse in the light of project overruns," IEEE Transactions on Engineering Management, vol. 52, no. 4, pp. 497-508, 2005.

[40] M. Kapsali, "Equifinality in project management exploring causal complexity in projects," Systems Research and Behavioral Science, vol. 30, no. 1, pp. 2-14, 2013.

[41] D. F. Mamedio and V. Meyer, "Managing project complexity: how to cope with multiple dimensions of complex systems," International Journal of Managing Projects in Business, vol. 13, no. $4,2020$.

[42] A. J. Edkins and H. J. Smyth, "Contractual management in PPP projects: evaluation of legal versus relational contracting for service delivery," Journal of Professional Issues in Engineering Education and Practice, vol. 132, no. 1, pp. 82-93, 2006.

[43] J. F. Y. Yeung, A. P. C. Chan, and D. W. M. Chan, "Defining relational contracting from the Wittgenstein family-resemblance philosophy," International Journal of Project Management, vol. 30, no. 2, pp. 225-239, 2012.

[44] E. Lau and S. Rowlinson, "Trust relations in the construction industry," International Journal of Managing Projects in Business, vol. 3, no. 4, pp. 693-704, 2010.

[45] B. L. Connelly, T. R. Crook, J. G. Combs, D. J. Ketchen Jr, and H. Aguinis, "Competence- and integrity-based trust in interorganizational relationships: which matters more?" Journal of Management, vol. 44, no. 3, pp. 919-945, 2018.

[46] S. O. Cheung, W. K. Wong, T. W. Yiu, and H. Y. Pang, "Developing a trust inventory for construction contracting," International Journal of Project Management, vol. 29, no. 2, pp. 184-196, 2011.

[47] A. Kadefors, "Trust in project relationships-inside the black box," International Journal of Project Management, vol. 22, no. 3, pp. 175-182, 2004.

[48] F. D. Schoorman, R. C. Mayer, and J. H. Davis, "An integrative model of organizational trust: past, present, and future," Academy of Management, Briarcliff Manor, NY, USA, 2007.

[49] X. Wang and Z. Yang, "Inter-firm opportunism: a metaanalytic review and assessment of its antecedents and effect on performance," Journal of Business \& Industrial Marketing, vol. 28, no. 2, pp. 137-146, 2013.
[50] P. S. Fong and B. W. Lung, "Interorganizational teamwork in the construction industry," Journal of Construction Engineering and Management, vol. 133, no. 2, pp. 157-168, 2007.

[51] M. M. Rahman and M. M. Kumaraswamy, "Relational contracting and teambuilding: assessing potential contractual and noncontractual incentives," Journal of Management in Engineering, vol. 24, no. 1, pp. 48-63, 2008.

[52] A. Zaheer, B. Mcevily, and V. Perrone, "Does trust matter? Exploring the effects of interorganizational and interpersonal trust on performance," Organization Science, vol. 9, no. 2, pp. 141-159, 1998.

[53] Y. Liu, Y. Luo, and T. Liu, "Governing buyer-supplier relationships through transactional and relational mechanisms: evidence from China," Journal of Operations Management, vol. 27, no. 4, pp. 294-309, 2009.

[54] J. Xu, L. Yuan, and S. Gao, "The stability of strategic alliances: characteristics, factors and stages," Journal of International Management, vol. 14, no. 2, pp. 173-189, 2008.

[55] L. A. Vidal and F. Marle, "Understanding project complexity: implications on project management," Kybernetes, vol. 37, no. 8, pp. 1094-1110, 2008.

[56] C. Moorman, R. Deshpande, and G. Zaltman, "Factors affecting trust in market research relationships," Journal of Marketing, vol. 57, no. 1, pp. 81-101, 1993.

[57] D. M. Kennedy, S. A. Mccomb, and R. R. Vozdolska, "An investigation of project complexity's influence on team communication using Monte Carlo simulation," 2011.

[58] J. P. Cannon, R. S. Achrol, and G. T. Gundlach, "Contracts, norms, and plural form governance," Journal of the Academy of Marketing Science, vol. 28, no. 2, pp. 180-194, 2000.

[59] S. S. Lui and H.-Y. Ngo, "The role of trust and contractual safeguards on cooperation in non-equity alliances," Journal of Management, vol. 30, no. 4, pp. 471-485, 2004.

[60] S. Wuyts and I. Geyskens, "The Formation of buyer-supplier relationships: detailed contract drafting and close partner selection," Journal of Marketing, vol. 69, no. 4, pp. 103-117, 2005.

[61] W. Xia and G. Lee, "Complexity of information systems development projects: conceptualization and measurement development," Journal of Management Information Systems, vol. 22, no. 1, pp. 45-83, 2005.

[62] P. M. Podsakoff, S. B. Mackenzie, J.-Y. Lee, and N. P. Podsakoff, "Common method biases in behavioral research: a critical review of the literature and recommended remedies," Journal of Applied Psychology, vol. 88, no. 5, p. 879, 2003.

[63] T. J. B. Kline, L. M. Sulsky, and S. D. Rever-Moriyama, "Common method variance and specification errors: a practical approach to detection," The Journal of Psychology, vol. 134, no. 4, pp. 401-421, 2000.

[64] E. Karadag, "Basic features of structural equation modeling and path analysis with its place and importance in educational research methodology," Bulgarian Journal of Science and Education Policy, vol. 6, no. 1, p. 194, 2012.

[65] C. Fornell and D. F. Larcker, "Evaluating structural equation models with unobservable variables and measurement error," Journal of Marketing Research, vol. 18, no. 1, pp. 39-50, 1981.

[66] J. C. Anderson and D. W. Gerbing, "Structural equation modeling in practice: a review and recommended two-step approach," Psychological Bulletin, vol. 103, no. 3, pp. 411-423, 1988.

[67] A. F. Hayes, "Beyond Baron and Kenny: statistical mediation analysis in the new millennium," Communication Monographs, vol. 76, no. 4, pp. 408-420, 2009. 
[68] Y. Li, E. Xie, H.-H. Teo, and M. W. Peng, "Formal control and social control in domestic and international buyer-supplier relationships," Journal of Operations Management, vol. 28, no. 4 , pp. 333-344, 2010.

[69] R. Dore, "Goodwill and the spirit of market capitalism," The British Journal of Sociology, vol. 34, no. 4, pp. 459-482, 1983.

[70] G. John, "An empirical investigation of some antecedents of opportunism in a marketing channel," Journal of Marketing Research, vol. 21, no. 3, pp. 278-289, 1984.

[71] X. Jiang, Y. Li, and S. Gao, "The stability of strategic alliances: characteristics, factors and stages," Journal of International Management, vol. 14, no. 2, pp. 173-189, 2008.

[72] Z. Yang, C. Zhou, and L. Jiang, "When do formal control and trust matter? A context-based analysis of the effects on marketing channel relationships in China," Industrial Marketing Management, vol. 40, no. 1, pp. 86-96, 2011.

[73] M.-C. Huang, H.-L. Cheng, and C.-Y. Tseng, "Reexamining the direct and interactive effects of governance mechanisms upon buyer-supplier cooperative performance," Industrial Marketing Management, vol. 43, no. 4, pp. 704-716, 2014.

[74] C. W. L. Hill, "Cooperation, opportunism, and the invisible hand: implications for transaction cost theory," Academy of Management Review, vol. 15, no. 3, pp. 500-513, 1990.

[75] S. D. Jap and E. Anderson, "Safeguarding interorganizational performance and continuity under ex post opportunism," Management Science, vol. 49, no. 12, pp. 1684-1701, 2003.

[76] M. Bresnen and N. Marshall, "Building partnerships: case studies of clientcontractor collaboration in the UK construction industry," Construction Management and Economics, vol. 18, no. 7, pp. 819-832, 2000.

[77] A. P. C. Chan, D. W. M. Chan, and K. S. K. Ho, "Partnering in construction: critical study of problems for implementation," Journal of Management in Engineering, vol. 19, no. 3, pp. 126-135, 2003.

[78] J. J. Li, L. Poppo, and K. Z. Zhou, "Relational mechanisms, formal contracts, and local knowledge acquisition by international subsidiaries," Strategic Management Journal, vol. 31, no. 4, pp. 349-370, 2010. 